22. Mudd, S. H., Finkelstein, J. D., Irreverre, F., and Laster, L.: Transsulfuration in mammals: Microassays and tissue distribution of three enzymes of the pathway. J. Biol. Chem., 240: 4382 (1965).

23. Natori, Y.: Studies on ethionine. VI. Sex-dependent behavior of methionine and ethionine in rats. J. Biol. Chem., 238: 2075 (1963).

24. Niemann, W.: Unpublished observations.

25. Pascal, T. A., Gillam, B. M., and Gaull, G. E.: Cystathionase: Immunochemical evidence for absence from human fetal liver. Pediat. Res., 6: 773 (1972).

26. Rose, W. C., and Wixom, R. L.: Amino acid requirements of man. XIII. Sparing effect of cystine on the methionine requirement. J. Biol Chem.,216.95 (1955).

27. Salerno, D. M., and Beeler, D. A.: The biosynthesis of phospholipids and their precursors in rat liver involving de novo methylation, and base-exchange pathways, in vivo. Biochim. Biophys. Acta, 326: 325 (1973).

28. Sturman, J. A., and Gaull, G. E.: Polyamine biosynthesis in human fetal liver and brain. Pediat. Res., 8: 321 (1974)

29. Sturman, J. A., and Gaull, G. E.: Unpublished studies.

30. Sturman, J. A., Gaull, G., and Räihä, N. C. R.: Absence of cystationase in human fetal liver: Is cystine essential? Science, 169: 74 (1970).

31. Sturman, J. A., Gaull, G. E., and Räihä, N. C. R.: DNA synthesis from the $\beta$-carbon of serine by fetal and mature human liver. Biol. Neonate, 27: 17 (1975).

32. Sturman, J. A., Niemann, W. H., and Gaull, G. E.: Metabolism of ${ }^{35}$ S-methionine and ${ }^{35} \mathrm{~S}$-cystine in the pregnant Rhesus monkey. Biol. Neonate, 21: 16 (1973).

33. Tallan, H. H.: Unpublished observations.

34. Tallan, H. H., Cohen, P. A., and Gaull, G. E.: Allosteric properties of rat liver methionine-activating enzyme. Fed. Proc., 31: 576 (1973).

35. Tallan, H. H., and Gaull, G. E.: Unpublished data.

36. Tanimura, T., Nelson, T., Hollingworth, R. R., and Shepard, T. H.: Weight standards for organs from early human fetuses. Anat. Rec., 171: 227 (1971)

37. Taylor, R. T., and Weissbach, H.: Radioactive assay for serine transhydroxymethylase. Anal, Biochem., 13: 80 (1965).

38. Villee, C. A., and Villee, D. B.: Respiratory Distress Syndrome Conference Proceedings (Academic Press, New York, 1973).

39. Wilson, J. D., Gibson, K. D., and Udenfriend, S.: Studies on the precursors of methyl groups of choline in rat liver. J. Biol. Chem., 235: 3213 (1960)

40. Zachmann, R. D.: The enzymes of lecithin biosynthesis in human newborn lungs. II.Methionine-activating enzyme and phophatidyl methyltransferase. Biol. Neonate, 20: 448 (1972)

41. We are grateful to Dr. Wendell Niemann for determination of gestational age in the monkeys. Mrs. Susan Sansevero gave expert technical assistance.

42. Dr. Sternowsky, on leave from the University of Hamburg, Pediatric Clinic, was the recipient of a grant from the Deutsche Forschungsgemeinschaft, Bad Godesberg.

43. This study was supported by the New York State Department of Mental Hygiene, National Institutes of Health Clinical Genetics Center Grant GM-19443, and the Sigrid Juselius Foundation.

44. Requests for reprints should be addressed to: G: Gaull, M.D., Department of Pediatric Research, New York State Institute for Basic Research in Mental Retardation, 1050 Forest Hill Rd., Staten Island, N.Y. 10314 (USA).

45. Aci epted for publication December 3, 1975.
Glycine intestine

iminoacids type I hyperprolinemia

\title{
Type I Hyperprolinemia: A Study of the Intestinal Absorption of Proline, Hydroxyproline, and Glycine
}

\author{
J. P. FARRIAUX (17) AND J. L. DHONDT
}

Laboratoire de Recherche, Clinique Pédiatrique, Cité Hospitalière, Lille, France

\section{Extract}

Intestinal absorption of proline, hydroxyproline, and glycine was interpreted by investigation of a type I hyperprolinemia patient and six control subjects. Intestinal perfusion was performed.

When proline (Pro), hydroxyproline (OH-Pro), and glycine (Gly) were infused together, an increase in proline concentration did not alter aminoacid uptake in the control subjects; however, in the hyperprolinemia patient, uptake of aminoacids became negligible (Pro, 17-6 $\mu \mathrm{M} / \mathrm{min}$; OH-Pro, 15-0.3 $\mu \mathrm{M} / \mathrm{min}$; and Gly, 13.5-0 $\mu \mathrm{M} / \mathbf{m i n})$.

When each aminoacid was infused alone at increasing concentrations aminoacid uptake increased in controls; in the hyperprolinemic patient, intestinal absorption was less for glycine and hydroxyproline but aminoacid uptake increased with substrate concentration; however, for proline, the uptake remained constant (16.5-17 $\mu \mathrm{M} / \mathrm{min} / 20 \mathrm{~cm}$ of intestinal test segment) (Table 1 ).

When hydroxyproline was infused with an increased concentration of proline in the hyperprolinemic patient, hydroxyproline uptake first increased $(9.8-14.3 \mu \mathrm{M} / \mathrm{min} / 20 \mathrm{~cm})$ then decreased to its basal value, whereas, in the control subjects, uptake increased without decreasing subsequently.

\section{Speculation}

The chronic hyperprolinemia state might entail adaptation of the transport mechanism with the three infused aminoacids (Pro, OH-Pro, and Gly), bringing about an "overflow" of the system similar to that observed in the kidney. However, the inhibition of intestinal iminoacids and glycine transport seems to be due to mechanisms more complex than that of a simple inhibition by proline.

The mechanisms of membrane transport of proline, hydroxyproline, and glycine have been investigated in some recent studies, the results of which seem to indicate the presence, in vivo, of a single transport system for iminoacids and glycine $(7,10,11,13)$.

Investigation of a type I hyperprolinemia patient allowed us to suggest a new approach to the problems of intestinal absorption of these three aminoacids.

\section{EXPERIMENTAL PROCEDURE}

\section{SUBJECTS}

The subjects were one patient with type I hyperprolinemia whose case is described in an earlier report (4) and six control subjects of the same age and weight as the propositus; none had evidence of small bowel or metabolic diseases and plasma aminoacid levels (Pro, Gly, OH-Pro) were normal.

\section{METHODS}

A method of intestinal perfusion with which we were already familiar was adopted (3). 
Intubation. This was carried out with a double lumen tube in accordance with the procedure previously described elsewhere (3).

Perfusion. Six intubations (one per week) were performed on the patient with hyperprolinemia, with the following infused solutions: (1) proline $(5,10,20,30$, and $40 \mathrm{mM}) ;(2)$ hydroxyproline $(5,10$, $20,30$, and $40 \mathrm{mM}) ;(3)$ glycine $(5,10,20,30$, and $40 \mathrm{mM}) ;(4)$ proline $(10,20$, and $40 \mathrm{mM})$-hydroxyproline $(10 \mathrm{mM}) ;(5)$ proline $(10,20$, and $40 \mathrm{mM})$-glycine $(10 \mathrm{mM}) ;(6)$ proline $(10,20$, and 40 $\mathrm{mM}$ )-hydroxyproline $(10 \mathrm{mM})$-glycine $(10 \mathrm{mM})$.

Samples. After an equilibration period $(40 \mathrm{mM})$ to allow examination of the composition of the intestinal fluid arriving in the test segment, three 10-min samples were taken for each concentration.

Assays. Aminoacids were estimated by ion exchange chromatography with a Unichrom-Beckman Auto Analyzer and polyethylene glycol (PEG) was estimated by Hyden's turbidimetric method (6).

Results. For each sample, absorption was calculated with correction of the dilution factor by the PEG determination (PEG 4,000 infused with the amino acid solution). For each infused concentration, we calculated the average of the sample results from the three $10-\mathrm{min}$ periods.

\section{RESULTS}

Our method did not allow an analytic study of all the variables present; compared the propositus (16) only with control subjects for each solution infused.

INTESTINAL ABSORPTION, WHEN PROLINE, HYDROXYPROLINE, OR GLYCINE WAS INFUSED ALONE, (TABLE 1)

Control Subjects. The quantity of aminoacid taken up (as expressed in micromolar concentration per min per $20 \mathrm{~cm}$ of intestinal test segment) increased with increasing substrate concentration.

Hyperprolinemic Patient. The intestinal absorption was less for glycine and hydroxyproline, but the aminoacid uptake increased with the substrate concentration. However, when a higher proline concentration was infused, the quantity of proline absorbed remained constant of $16.5-17 \mu \mathrm{M} / \mathrm{min}$.

\section{INTESTINAL ABSORPTION WITH INFUSIONS OF AMINOACID MIX- TURES}

Proline-glycine infusion. In the control subjects proline uptake increased but did not alter the glycine uptake, which remained constant $(20-21.5 \mu \mathrm{M} / \mathrm{min} / 20 \mathrm{~cm})$. In the hyperprolinemia patient, the proline uptake increased (from 7 to 32.5 ), whereas the glycine uptake decreased (Table 2). Unfortunately, we were unable to make the $40 \mathrm{mM}$ infusion for technical reasons.)

Proline-Hydroxyproline Infusion. In the control subjects both proline and hydroxyproline uptake increased, although only the proline concentration in the infused solution was increased. In the patient, when the concentration of infused proline was raised, the absorption rate of proline increased whereas that of hydroxypro-

Table 1. Intestinal absorption of proline (Pro), hydroxyproline (OH-Pro), and glycine (Gly) (aminoacids infused alone)

\begin{tabular}{|c|c|c|c|c|c|c|}
\hline & \multicolumn{6}{|c|}{ Intestinal absorption, $\mu \mathrm{M} / \mathrm{min} / 20 \mathrm{~cm}$} \\
\hline & \multicolumn{2}{|c|}{ Pro } & \multicolumn{2}{|c|}{ OH-Pro } & \multicolumn{2}{|c|}{ Gly } \\
\hline & Controls & Patient & Controls & Patient & Controls & Patient \\
\hline $5 \mathrm{mM}$ & 4.1 & & 7.9 & & 8.8 & \\
\hline $10 \mathrm{mM}$ & 13.8 & 16.8 & 17.5 & 5.8 & 16.5 & 14 \\
\hline $20 \mathrm{mM}$ & 22 & 16.5 & 32 & 19.5 & 43.5 & 25 \\
\hline $30 \mathrm{mM}$ & 41.4 & & 63 & & 66 & \\
\hline $40 \mathrm{mM}$ & & & & 35 & & 50 \\
\hline
\end{tabular}

Table 2. Intestinal absorption $(\mu M / \min / 20 \mathrm{~cm})$ of proline (Pro)-glycine (Gly) mixture

\begin{tabular}{lllllll}
\hline & \multicolumn{2}{c}{ Control subjects } & & \multicolumn{2}{c}{ Patient } \\
\cline { 2 - 3 } \cline { 5 - 6 } & Pro & Gly & & Pro & Gly \\
\hline Gly 10 mM + Pro 10 mM & 22 & 21.5 & & 7 & 21 \\
Gly 10 mM + Pro 20 mM & 41 & 20.7 & & 32.5 & 15.3 \\
Gly 10 mM + Pro 40 mM & 80 & 20 & & \\
\hline
\end{tabular}

Table 3. Intestinal absorption $(\mu M / \mathrm{min} / 20 \mathrm{~cm})$ of proline (Pro)-hydroxyproline (OH-Pro) mixture

\begin{tabular}{lccclrr}
\hline & \multicolumn{2}{c}{ Control subjects } & & \multicolumn{2}{c}{ Patient } \\
\cline { 2 - 3 } \cline { 5 - 6 } \cline { 5 - 6 } & Pro & OH-Pro & & Pro & OH-Pro \\
\hline OH-Pro 10 mM + Pro 10 mM & 5.5 & 4 & & 14 & 9.8 \\
OH-Pro 10 mM + Pro 20 mM & 37 & 6.5 & & 32.5 & 14.3 \\
OH-Pro 10 mM + Pro 40 mM & 47 & 15.5 & & 36 & 9.8 \\
\hline
\end{tabular}

Table 4. Intestinal absorption $(\mu \mathrm{M} / \mathrm{min} / 20 \mathrm{~cm})$ of proline (Pro)-hydroxyproline (OH-Pro)-glycine (Gly) mixture

\begin{tabular}{|c|c|c|c|c|c|c|}
\hline & \multicolumn{3}{|c|}{ Control subjects } & \multicolumn{3}{|c|}{ Patient } \\
\hline & Pro & OH-Pro & Gly & Pro & OH-Pro & Gly \\
\hline $\begin{array}{l}\text { OH-Pro } 10 \mathrm{mM} \text { - } \\
\text { Gly } 10 \mathrm{mM} \text { - } \\
\text { Pro } 10 \mathrm{mM}\end{array}$ & 12.5 & 10 & 12.5 & 17 & 15 & 13.5 \\
\hline $\begin{array}{l}\text { OH-Pro } 10 \mathrm{mM} \text { - } \\
\text { Gly } 10 \mathrm{mM}- \\
\text { Pro } 20 \mathrm{mM}\end{array}$ & 23 & 12.8 & 11.8 & 21 & 5.8 & 9 \\
\hline $\begin{array}{l}\text { OH-Pro } 10 \mathrm{mM} \text { - } \\
\text { Gly } 10 \mathrm{mM} \text { - } \\
\text { Pro } 40 \mathrm{mM}\end{array}$ & 58 & 9 & 14.5 & 6 & 0.3 & 0 \\
\hline
\end{tabular}

line first increased $(9.8-14.3 \mu \mathrm{M} / \mathrm{min})$ and then decreased to its basal value (14.3-9.8 $\mu \mathrm{M} / \mathrm{min}$ ) (Table 3 ).

Proline-Hydroxyproline-Glycine Infusion. In the control subjects, hydroxyproline and glycine uptake was not significantly altered when proline uptake increased $(12.5-58 \mu \mathrm{M} / \mathrm{min})$. In the patient, raising the concentration of infused proline was accompanied by a large decrease in uptake of all aminoacids; uptake became negligible (Table 4).

\section{DISCUSSION}

In hyperprolinemia, the typical "combined" aminoaciduria (proline, hydroxyproline, and glycine) has been interpreted by Scriver (11) in relation to an inhibition of aminoacid transport in the renal tubule. Among the known transport systems are (I) two types of genetically controlled mechanism $(10,12)$ : the first of these, a common system, has low specificity and high capacity; the other has lower capacity and high substrate specificity for either iminoacids or glycine; (2) other more dissociated mechanisms apparently existing in the kidney $(5,8)$.

Is this conception of membrane transport applicable to the small bowel? In attempting to find an answer to this question we feel that the following observations arising from our study are particularly significant. (I) The control subjects do not show any significant inhibition of transport, which allows us to assume the apparent independance of glycine, proline, hydroxyproline transports; however, this is perhaps due to our relatively limited protocol (3). (2) The hyperprolinemic patient exhibits a special state characterized by a high proline concentration in all body fluids. In an identical 
case, Dodinval (2) indicates the competitive inhibition of hydroxyproline and glycine uptake by proline in the kidney. During a proline load, an "overflow stage" occurs with an increase in the clearance of three aminoacids, followed by a decrease in clearances to basal values ("recovery stage"). This probably corresponds to a tubular adaptation of the transport system and is perhaps dependent on the induction of an enzymatic system.

The studies on our hyperprolinemic patient may lead to two conclusions. (1) During the perfusion of the three aminoacids, one by one, uptake of both glycine and hydroxyproline increased, but by lower amounts than in the control subjects. On the contrary, the proline uptake remained constant $(16.5-17 \mu \mathrm{M} / \mathrm{min})$ despite the increase of infused proline concentration; this makes us believe that the transport systems are saturated, particularly that for proline. (2) The proline-hydroxyproline and proline-glycine infusions involve similar variations of proline uptake for the hyperprolinemic patient and the control subjects, still, however, with lower values for the patients. However, glycine and hydroxyproline uptake differs in the patient (Tables 2 and 3); therefore, transports for these aminoacids seem to be slightly inhibited. (3) During the proline-hydroxyproline-glycine infusion in the patient, marked and general decrease in absorption appears.

The chronic hyperprolinemia state might therefore entail adap. tation for the transport system, which would account for the low differences of absorption between the patient and the control subjects when aminoacids are infused one by one or two by two. On the other hand, when the three amino acids are infused together, an "overflow stage," similar to that observed by Dodinval in the kidney (2), appears, which is responsible for the fall in uptake of the three aminoacids.

In summation, the intestinal iminoacids and glycine transport seems to be due to complex mechanisms. (I) In normal subjects, glycine, proline, and hydroxyproline absorptions seem to be independent from one another. (2) In the hyperprolinemic patient, a strong inhibition of these transports occurs only when the three aminoacids are infused together and with an increasing concentration of proline. It remains that the values of aminoacid uptake are lower in the hyperprolinemic subject than in the control subject, a consequence perhaps of the fact that the patient with hyperprolinemia exhibits a special state characterized by a constant "overflow" of proline.

\section{SUMMARY}

Carrying out an investigation on a type I hyperprolinemia patient, our aim was to study iminoacids and glycine intestinal absorption.

Copyright (c) 1976 International Pediatric Research Foundation, Inc
It is difficult to compare the intestinal absorption mechanisms with those of the kidney. However, it appears that in the hyperprolinemic patient the intestinal absorption is not really disturbed, but the adaptation possibilities by comparison with control subjects are limited, particularly when hydroxyproline and glycine are infused with proline.

\section{REFERENCES AND NOTES}

1. Baerlocher, K. E.: Developmental aspects of aminoacid transport. In: Hommes, F. A. and C. J. Van Den Berg: Inborn Errors of Metabolism, p. 143 (Academic Press, New York, 1973).

2. Dodinval, P., Willems, L., Heusden, A. M., Hainaut, H., and Gottschalk, L. Clearance renale des acides aminés chez un enfant hyperprolinémique. J. Génét. Hum., 17: 297 (1969).

3. Farriaux, J. P., Delhaye, J. P., and Fontaine, G.: Etude de l'absorption intestinale des acides aminés chez le sujet phénylcétonurique par la méthode de perfusion intestinale continue. Pathol. Biol., 20: 543 (1972).

4. Fontaine, G., Farriaux, J. P., and Dautrevaux, M.: L'hyperprolinémie de type I-Etude d'une observation familiale. Helv. Paediat. Acta, 25: 156 (1970).

5. Hillman, R. E., and Rosenberg, L. E.: Aminoacid transport by isolated mammalian renal tubules. I. Transport systems for L-proline J. Biol. Chem., 244: 4494 (1969).

6. Hyden, S.: A turbidimetric method for the determination of higher polyethylene glycols in biological materials. Kgl. Lantbruckshögsköl. Ann., 22: 139 (1956).

7. Moatti, N., and Lemonnier, A.: Les systèmes de transfert des acides aminés et leur importance en pathologie. I. Modalités du transfert des acides aminés au niveau rénal et intestinal. Ann. Biol. Clin., 31: 175 (1973).

8. Mohyuddin, F., and Scriver, C. R.: Aminoacid transport in mammalian kidney: Multiple systems for iminoacids and glycine in rat kidney. Amer. J. Physiol., 219: 1 (1970).

9. Rey, F., Drillet, F., Schmitz, J., and Rey, J.: Influence of flow rate on the kinetics of the intestinal absorption of glucose and lysine in children. Gastroenterology, 66: 79 (1974).

10. Scriver, C. R., and Wilson, O. H.: Aminoacid transport: Evidence for genetic control of two types in human kidney. Science, 155: 1428 (1967).

11. Scriver C. R.: Membrane transport in disorders of iminoacid metabolism. Amer J. Dis. Child., 113: 170 (1967).

12. Scriver, C. R.: Renal tubular transport of proline, hydroxyproline and glycine. III. Genetic basis for more than one mode of transport in human kidney. J. Clin. Invest., 47: 823 (1968).

13. Wilson, O. H., and Scriver, C. R.: Specificity of transport of neutral and basic aminoacids in rat kidney. Amer. J. Physiol., 213: 185 (1967).

14. All through this study the patient plasma proline levels were $8.3 \pm 1.6 \mathrm{mg} / 100 \mathrm{ml}$.

15. The authors are indebted to Professor C. R. Scriver (McGill University-Montreal Children's Hospital-Research Institute) for his advice during the preparation of this manuscript.

16. Informed consent was obtained for all the studied subjects from their parents.

17. These investigations were supported in part by Grant from the UER 3 of "Université du Droit et de la Santé" Lille, France.

18. Requests for reprints should be addressed to: Prof. J. P. Farriaux, Clinique Pédiatrique (Prof. G. Fontaine), Cité Hospitalière, 59000 Lille (France).

19. Accepted for publication December 3, 1975. 